\title{
In vitro antimicrobial activity of ethanolic extracts obtained from Ficus spp. leaves against the fish pathogen Aeromonas hydrophila
}

\author{
Halyna Tkachenko, Lyudmyla Buyun, Elżbieta Terech-Majewska, Zbigniew Osadowski
}

Received - 01 August 2016/Accepted - 18 November 2016. Published online: 31 December 2016; @Inland Fisheries Institute in Olsztyn, Poland

Citation: Tkachenko H., Buyun L., Terech-Majewska E., Osadowski Z. 2016 - In vitro antimicrobial activity of ethanolic extracts obtained from Ficus spp. leaves against the fish pathogen Aeromonas hydrophila - Arch. Pol. Fish. 24: 219-229.

\begin{abstract}
The main goal of this study was to determine in vitro antimicrobial activity of ethanolic extracts obtained from the leaves of various Ficus species against Aeromonas hydrophila isolated locally from infected rainbow trout (Oncorhynchus mykiss Walbaum) with the aim of providing scientific rationale for the use of the plant in the treatment of bacterial infections induced by Aeromonas spp. in fish. Antimicrobial susceptibility testing was done on Muller-Hinton agar with the disc diffusion method. In the present study, most ethanolic extracts proved effective against the A. hydrophila tested, with 10-12 mm inhibition zones observed. A. hydrophila demonstrated the highest susceptibility to $F$. pumila. Among various species of Ficus with moderate activity against $A$. hydrophila, the highest antibacterial activities were noted for $F$. benghalensis, $F$. benjamina, F. deltoidea, F. hispida, and F. lyrata. Thus, Ficus can be used as a natural antiseptic and antimicrobial agent in veterinary practice. Further investigations need to be conducted to isolate and identify the bioactive compounds
\end{abstract}

\footnotetext{
H. Tkachenko [ $\left.\Xi^{\circ}\right]$, Z. Osadowski

Institute of Biology and Environmental Protection

Pomeranian University in Slupsk, Poland

Arciszewskiego 22B, 76-200 Slupsk, Poland

e-mail: tkachenko@apsl.edu.pl,biology.apsl@gmail.com

L. Buyun

M. Gryshko National Botanical Garden, National Academy of Science of Ukraine, Kyiv, Ukraine

E. Terech-Majewska

Department of Epizootiology, University of Warmia and Mazury in Olsztyn, Poland
}

that can then be subjected to detailed pharmacological studies and the development of clinical applications. The alarming rate of increasing resistance in bacterial pathogens in aquaculture environments means that medicinal plants with antibacterial properties are very important as natural resources of new active compounds.

Keywords: antibacterial activity, Aeromonas hydrophila, infected rainbow trout, Ficus spp., ethanolic extracts, growth inhibition zone

\section{Introduction}

Aeromonas hydrophila, a Gram-negative facultative anaerobe, is an autochthonous species in freshwater environments and a component of the normal microflora of fish intestinal tracts (Cipriano 2001). Aeromonas bacteria are also the etiologic agents responsible for a variety of infections in both immunocompetent and immunocompromised humans (Austin and Austin 2007). The severity of disease it causes is influenced by a number of interrelated factors, including bacterial virulence, the kind and degree of stress exerted on a fish population, and the resistance and physiological condition of the host. Pathologic conditions attributed to members of the A. hydrophila complex include dermal ulceration, hemorrhagic septicemia, red sore disease,

(c) Copyright by Stanisław Sakowicz Inland Fisheries Institute in Olsztyn.

(c) 2016 Author(s). This is an open access article licensed under the Creative Commons Attribution-NonCommercial-NoDerivs License (http://creativecommons.org/licenses/by-nc-nd/3.0/). 
red rot disease, and scale protrusion disease (Cipriano 2001). In salmonids, A. salmonicida causes furunculosis, a disease characterized by skin ulcers and septicemia. Moreover, other Aeromonas species are involved in similar pathological diseases (Austin and Austin 2007). Zepeda-Velázquez et al. (2015) confirm that the Aeromonas species $A$. hydrophila, A. salmonicida, and $A$. veronii are associated with septicemia and dermal lesions in rainbow trout. Furthermore, some fish bacterial pathogens are also associated with diseases in humans, which suggests that aquaculture products pose a potential risk to consumers (Tukmechi et al. 2010).

One of the overriding considerations is how disease can be controlled. While vaccine development has been focused less on motile aeromonads than on other pathogens, current research addresses the use of probiotics, immunostimulants, and medicinal plants, some of which stimulate immune memory, to control them (Cipriano and Austin 2011). The benefits of medicinal plants have been the focus of many Asian studies on controlling infections caused by Aeromonas (Cipriano and Austin 2011). Preliminary screening assays indicate that some plants with antibacterial properties can be used as alternative therapeutic agents against bacterial infections in the aquaculture industry. Increasing numbers of studies on the antimicrobial properties of medicinal herbs are being reported from different parts of the world. For instance, two Chinese medicinal herbs (Astragalus membranaceus and Lonicera japonica) administered at doses of $0.1 \%$ in combination with $0.5 \%$ boron for four weeks led to greatly reduced mortality in Nile tilapia, Oreochromis niloticus (L.), after they were challenged with A. hydrophila, and there was also evidence of immunostimulation (Ardo et al. 2008). An aqueous leaf extract of the Indian medicinal herb Azadirachta indica was tested against $A$. hydrophila infection in common carp, Cyprinus carpio L., and the results indicate in vitro inhibitory activity against this bacterium (Harikrishnan and Balasundaram 2005). The benefit of using $5 \mathrm{~g}$ of mango (Mangifera indica) kernel per $\mathrm{kg}$ of feed administered orally for 60 days to carp fingerlings was highlighted by Sahu et al. (2007), who report almost complete survival (98\% survival compared with $50 \%$ survival of the controls) after a challenge with $A$. hydrophila (Cipriano and Austin 2011).

Ginger (Zingiber officinale Roscoe) and guava (Psidium guajava L.) are promising food additives that can be used in carp aquaculture. The evaluation of the effects of ginger as a feeding supplement on the growth, skin mucus immune parameters, and cytokine-related gene expression of Labeo rohita (Hamilton), and its susceptibility to A. hydrophila infection was studied by Sukumaran et al. (2016). Ginger dietary supplements (at $0.8 \%$ ) can promote growth performance, skin mucus immune parameters, and strengthen immunity in L. rohita. The expression of gene encoding pro-inflammatory cytokines (IL-1 TNF- $\alpha$ ), signaling molecules Kelch-like-ECH-associated protein 1 (Keap1), and nuclear factor kappa B p65 (NF- $\kappa \mathrm{Bp} 65)$ were down-regulated in treatment groups. Moreover, fish fed a diet supplemented with $0.8 \%$ ginger exhibited significantly higher relative post-challenge survival $(65.52 \%)$ against A. hydrophila infection. Dietary supplementation with guava leaves (at $0.5 \%$ concentration) could also improve the growth performance and strengthen the immunity of L. rohita (Giri et al. 2015). Lysozyme levels, leukocyte phagocytic activity, and alternative complement pathway activity were significantly higher in the group fed guava. Moreover, the fish fed the guava diet exhibited a significantly higher post-challenge survival rate (66.7\%) (Giri et al. 2015).

Bacterial resistance to antibiotics is increasing, and the threats posed by the resistance of bacterial strains that have disseminated widely in aquaculture environments have never been greater. In recent years, there has been a growing interest in researching and developing new antimicrobial agents from various plants to overcome microbial resistance. Therefore, greater attention is being paid to screening antimicrobial activity and evaluating methods. Consequently, a number of medicinal plants have been screened for antimicrobial activity against Gram-positive and Gram-negative bacteria in recent 
years. The active compounds of herbs possess characteristics that could be useful in fish and shrimp culture, and various herbs stimulate growth and appetite, enhance immune system responses, and exhibit broad-spectrum antimicrobial activity (Friedman et al. 2002). In particular, there has been increasing interest in Ficus spp. (Moraceae) because of its chemical composition and potential health benefits. Ficus spp. have been used extensively in traditional medicine for a wide range of ailments of the central nervous system, endocrine system, gastrointestinal tract, reproductive system, respiratory system, and infectious disorders (Ahmad et al. 2011, Ilyanie et al. 2011, Dangarembizi et al. 2012, Arunachalam and Parimelazhagan 2013, Gul-e-Rana et al. 2013, Farsi et al. 2014). However, although many species from the genus Ficus have been subjected to phytochemical and pharmacological investigations, there are many species that have not been studied and the ethnobotanical relevance of them has yet to be investigated. Therefore, an attempt was made to determine the in vitro antimicrobial activity of ethanolic extracts from the leaves of various Ficus species against the bacterial strain of $A$. hydrophila isolated locally from infected rainbow trout (Oncorhynchus mykiss Walbaum) with the aim of providing scientific rationale for using these plants in the treatment of bacterial infections induced by Aeromonas spp. in fish.

\section{Materials and methods}

\section{Collection of plant material}

The leaves of F. aspera G. Forst, F. benghalensis L., F. benjamina L., $F$. benjamina "Reginald", $F$. binnendijkii (Miq.) Miq., F. binnendijkii "Amstel Gold”, F. binnendijkii “Amstel King”, F. binnendijkii “Amstel Gold”, F. carica L., F. craterostoma Mildbr. \& Burret, F. cyathistipula Warb., F. deltoidea Jack, F. drupacea Thunb., F. drupacea "Black Velvet", F. elastica Roxb., F. elastica "Variegata", F. erecta Thunb., F. erecta var. sieboldii (Miq.) King, F. hispida
L.f., F. luschanthiana (Miq.) Miq., F. lyrata Warb., F. macrophylla Desf. ex Pers., F. mucuso Welw. ex Ficalho, F. natalensis Hochst. subsp. natalensis, $F$. natalensis Hochst. subsp. leprieurii (Miq.) C.C. Berg, F. palmeri S.Watson, F. platypoda (Miq.) A. Cunn. ex Miq., F. pumila L., F. religiosa L., F. rubiginosa Desf. ex Vent., F. sagittata J. Koenig ex Vahl, F. septica Burm. f., F. sur Forssk., F. sycomorus L., F. vasta Forssk., F. villosa Blume were collected in the M. Gryshko National Botanical Garden (NBG) (Kyiv, Ukraine) during March and September of 2015. The entire collection of tropical and subtropical plants at NBG (including Ficus spp. plants) is classified as being from the National Heritage Collection of Ukraine. The species author abbreviations were taken from Brummitt and Powell (1992), Davis and Schmidt (1996), Jones et al. (1997).

\section{Preparation of plant extracts}

The Ficus spp. leaves sampled were brought into the laboratory for antimicrobial studies. Freshly crushed leaves were washed, weighed, and homogenized in $96 \%$ ethanol (in a proportion of 1:10) at room temperature, and centrifuged at 3,000 g for 5 minutes. Supernatants were stored at $-20^{\circ} \mathrm{C}$ in bottles protected with laminated paper until required.

\section{Identification method of the bacteria}

A. hydrophila (strain E 2/7/15) isolated locally from the gills of rainbow trout (Oncorhynchus mykiss Walbaum) with clinical symptoms of furunculosis (the kidneys were gray, the liver was pale and fragile, the enlarged was spleen with exudate was noted in the body cavity) was used as the test organism. Samples of internal organs (kidneys, spleen, liver) weighing $2 \mathrm{~g}$ were taken and homogenized before preincubation in Tripticase Soya Broth (TSB; Oxoid) for $24 \mathrm{~h}$. After preincubation, the bacterial culture was transferred to two different cultivation media: Tripticase Soya Agar (TSA; Oxoid) and Brain Heart Infusion Agar (BHIA; Oxoid ) supplemented with 5\% sheep blood (OIE 2000). After $48 \mathrm{~h}$ of incubation at 
$27^{\circ} \mathrm{C}$, characteristic pink colonies were selected for further examination. The bacteria species were identified using an oxidase test and an API E test kit (Biomerieux, France). The results of the test were interpreted according to the manufacturer's protocol after $24 \mathrm{~h}$ of incubation at $27^{\circ} \mathrm{C}$. Codes $++\mathrm{V}-\mathrm{V}----\mathrm{V}+++---+-\mathrm{VV}+$ in the API E test were identified as $A$. hydrophila. The strain was obtained from the Diagnostics Laboratory of Fish and Crayfish Diseases, Department of Veterinary Hygiene, Provincial Veterinary Inspectorate in Olsztyn (Poland).

\section{Bacterial growth inhibition test of plant extracts by the disk diffusion method}

The strain tested was plated on TSA medium and incubated for $24 \mathrm{~h}$ at $25^{\circ} \mathrm{C}$. Then the microorganism suspensions were suspended in sterile PBS, and turbidity was adjusted to the equivalent of the 0.5 McFarland standard. The antimicrobial activity of the extracts was evaluated with the agar well diffusion method (Bauer et al. 1966). Muller-Hinton agar plates were inoculated with $400 \mu \mathrm{l}$ of standardized

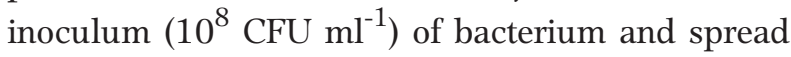
with sterile swabs.

Sterile filter paper discs impregnated with extract were applied to each of the culture plates $15 \mathrm{~min}$ after the bacteria suspension had been applied. The antimicrobial susceptibility testing was done on Muller-Hinton agar with the disc diffusion method (Kirby-Bauer disk diffusion susceptibility test protocol). The A. hydrophila isolates were tested individually against four antibiotics. The antibiotics tested were oxytetracycline $(30 \mu \mathrm{g})$, enrofloxacin $(5 \mu \mathrm{g})$, gentamicin $(10$ $\mu \mathrm{g})$, and sulphamethoxazole/trimethoprim (25 $\mu \mathrm{g})$. A negative control disc impregnated with sterile ethanol was used in each experiment. The sensitivity of the strain to a commercial preparation with garlic extract (in dilution 1:10, 1:100, and 1:1000) was also studied. After culturing bacteria on Mueller-Hinton agar, the disks were placed on the same plates and incubated for $24 \mathrm{~h}$ at $25^{\circ} \mathrm{C}$. The diameters of the inhibition zones were measured in millimeters and compared with those of the control and standard susceptibility disks.
Activity was evidenced by the presence of inhibition zones surrounding the well. Each test was repeated six times, and the average values of antimicrobial activity were calculated.

The following zone diameter criteria were used to assign bacterial susceptibility or resistance to the phytochemicals tested: Susceptible (S) $\geq 15 \mathrm{~mm}$, Intermediate $(\mathrm{I})=11-14 \mathrm{~mm}$, and Resistant $(\mathrm{R}) \leq 10$ mm (Okoth et al. 2013).

\section{Results}

The data on the antimicrobial potential of ethanolic extracts obtained from Ficus spp. leaves are presented in Table 1 and Figs. 1-3. A comparison of susceptibility categories, i.e., susceptible, intermediate, and resistant, for the disk diffusion method is shown in Table 1.

The results indicated that the A. hydrophila (400 $\mu \mathrm{l}$ of standardized inoculum) revealed intermediate susceptibility to ethanolic extracts obtained from $F$. benghalensis, $F$. benjamina, $F$. benjamina "Reginald", F. binnendijkii, F. carica, F. cyathistipula, F. deltoidea, F. drupacea, F. drupacea "Black Velvet", F. elastica, F. erecta, F. erecta var. sieboldii, F. hispida, F. lyrata, $F$. macrophylla, $F$. natalensis subsp. leprieurii, $F$. natalensis subsp. natalensis, F. palmeri, F. religiosa, F. rubiginosa, F. septica, and F. sycomorus. A. hydrophila possessed resistance against ethanolic extracts from $F$. aspera, F. binnendijkii “Amstel Gold”, F. binnendijkii "Amstel King”, F. craterostoma, F. elastica "Variegata", F. luschanthiana, F. mucuso, F. platypoda, F. sagittata, F. sur, F. vasta, and F. villosa. The highest susceptibility of $A$. hydrophila was observed to $F$. pumila (the mean diameter of the inhibition zone was $17.1 \mathrm{~mm}$ ) (Table 1).

\section{Discussion}

The results indicated that extracts offer a promising alternative to the use of antibiotics in controlling the growth of $A$. hydrophila. In this study, most ethanolic 
Table 1

Susceptibility or resistance of $A$. hydrophila against ethanolic extracts obtained from Ficus spp. leaves

\begin{tabular}{|c|c|c|c|}
\hline \multirow[b]{2}{*}{ Ficus spp. } & \multicolumn{3}{|c|}{ Susceptibility or resistance of $A$. hydrophila } \\
\hline & Susceptible $(S) \geq 15 \mathrm{~mm}$ & Intermediate $(\mathrm{I})=11-14 \mathrm{~mm}$ & Resistant $(\mathrm{R}) \leq 10 \mathrm{~mm}$ \\
\hline F. aspera & & & + \\
\hline F. benghalensis & & + & \\
\hline F. benjamina & & + & \\
\hline F. benjamina "Reginald" & & + & \\
\hline F. binnendijkii & & + & \\
\hline F. binnendijkii "Amstel Gold" & & & + \\
\hline F. binnendijkii "Amstel King" & & & + \\
\hline F. carica & & + & \\
\hline F. craterostoma & & & + \\
\hline F. cyathistipula & & + & \\
\hline F. deltoidea & & + & \\
\hline F. drupacea & & + & \\
\hline F. drupacea "Black Velvet" & & + & \\
\hline F. elastica & & + & \\
\hline F. elastica "Variegata" & & & + \\
\hline F. erecta & & + & \\
\hline F. erecta var. sieboldii & & + & \\
\hline F. hispida & & + & \\
\hline F. luschanthiana & & & + \\
\hline F. lyrata & & + & \\
\hline F. macrophylla & & + & \\
\hline F. mucuso & & & + \\
\hline F. natalensis subsp. leprieurii & & + & \\
\hline F. natalensis subsp. natalensis & & + & \\
\hline F. palmeri & & + & \\
\hline F. platypoda & & & + \\
\hline F. pumila & + & & \\
\hline$F$. religiosa & & + & \\
\hline F. rubiginosa & & + & \\
\hline F. sagittata & & & + \\
\hline F. septica & & + & \\
\hline F. sur & & & + \\
\hline F. sycomorus & & + & \\
\hline F. vasta & & & + \\
\hline F. villosa & & & + \\
\hline
\end{tabular}



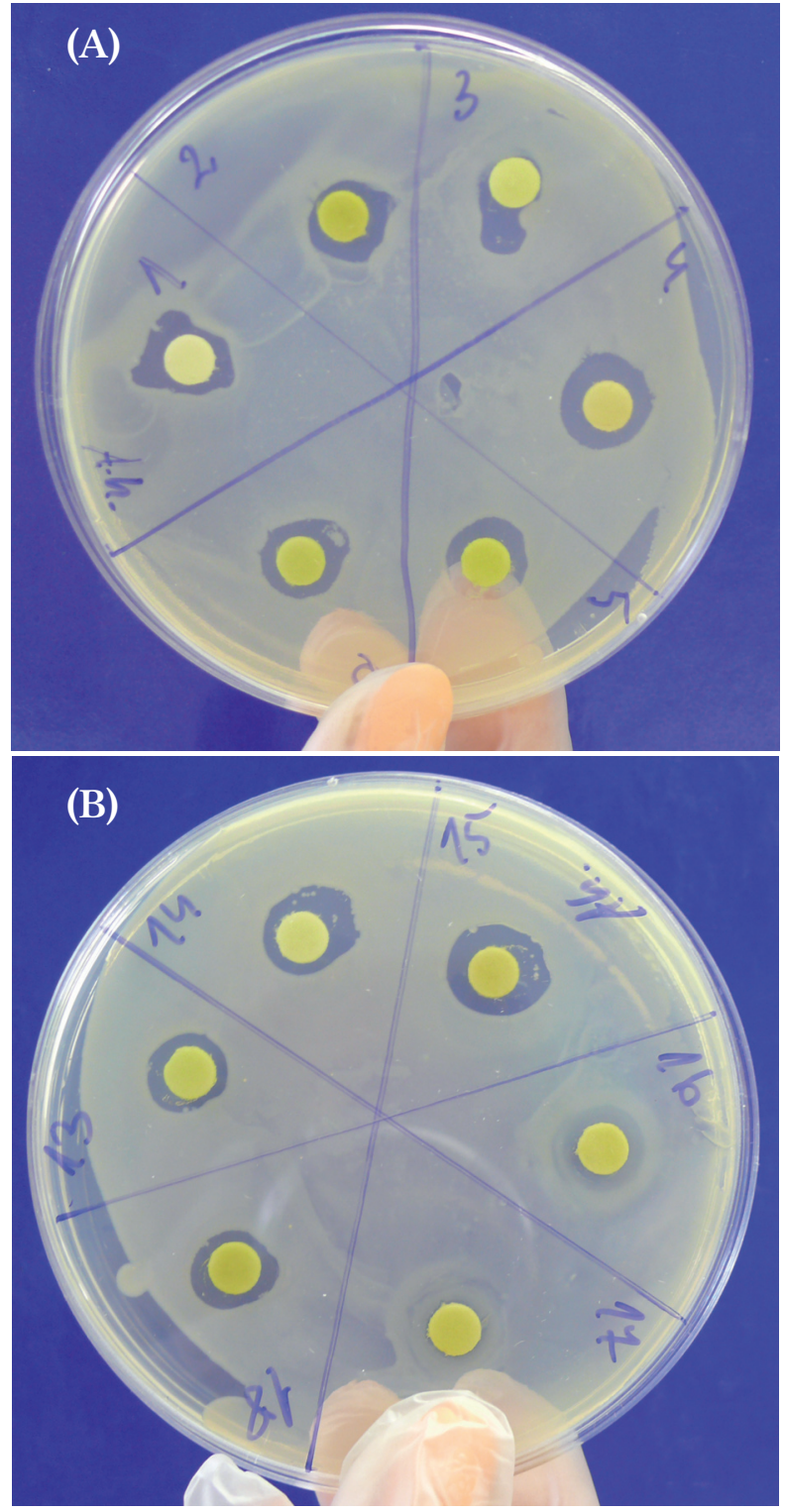

Figure 1. Antimicrobial activity of ethanolic extracts obtained from $F$. benghalensis (4), F. benjamina (5) (A), $F$. cyathistipula (14), and $F$. lyrata (15) against $A$. hydrophila (B) measured as inhibition zone diameter.

extracts obtained from Ficus spp. proved effective against the bacterial strain of Gram-negative $A$. hydrophila tested with 10-12 mm inhibition zones observed. A. hydrophila demonstrated the highest susceptibility to F. pumila (Table 1, Fig. 3).

It is well documented that various Ficus spp. have been used against Gram-positive and Gram-negative bacteria (Salem et al. 2013). The scientific research on
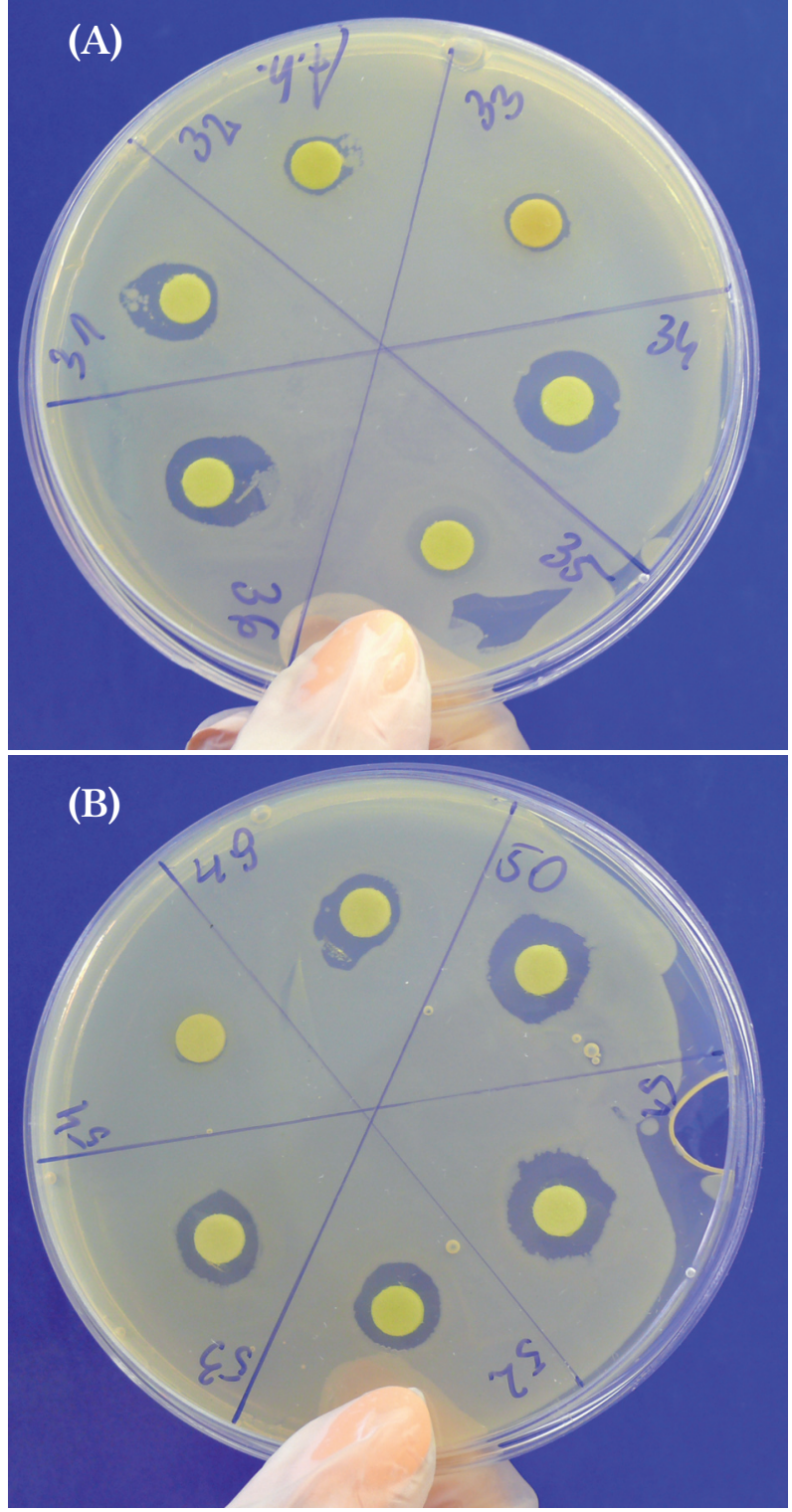

Figure 2. Antimicrobial activity of ethanolic extracts obtained from $F$. natalensis subsp. leprieurii (34) and $F$. deltoidea (36) (A), F. palmeri (50), F. hispida (51), and $F$. natalensis subsp. natalensis (52) against $A$. hydrophila (B) measured as inhibition zone diameter.

Ficus spp. indicates that these plants have been of increasing interest in recent years. For example, bergapten and oxypeucedanin hydrate were isolated from the chloroform extract of F. pumila (Juan et al. 1997). Bergapten was found to inhibit the growth of Staphylococcus aureus, Escherichia coli, and Salmonella typhi, but it was inactive against Trichophyton mentagrophytes, Mycobacterium pleie, and Candida 

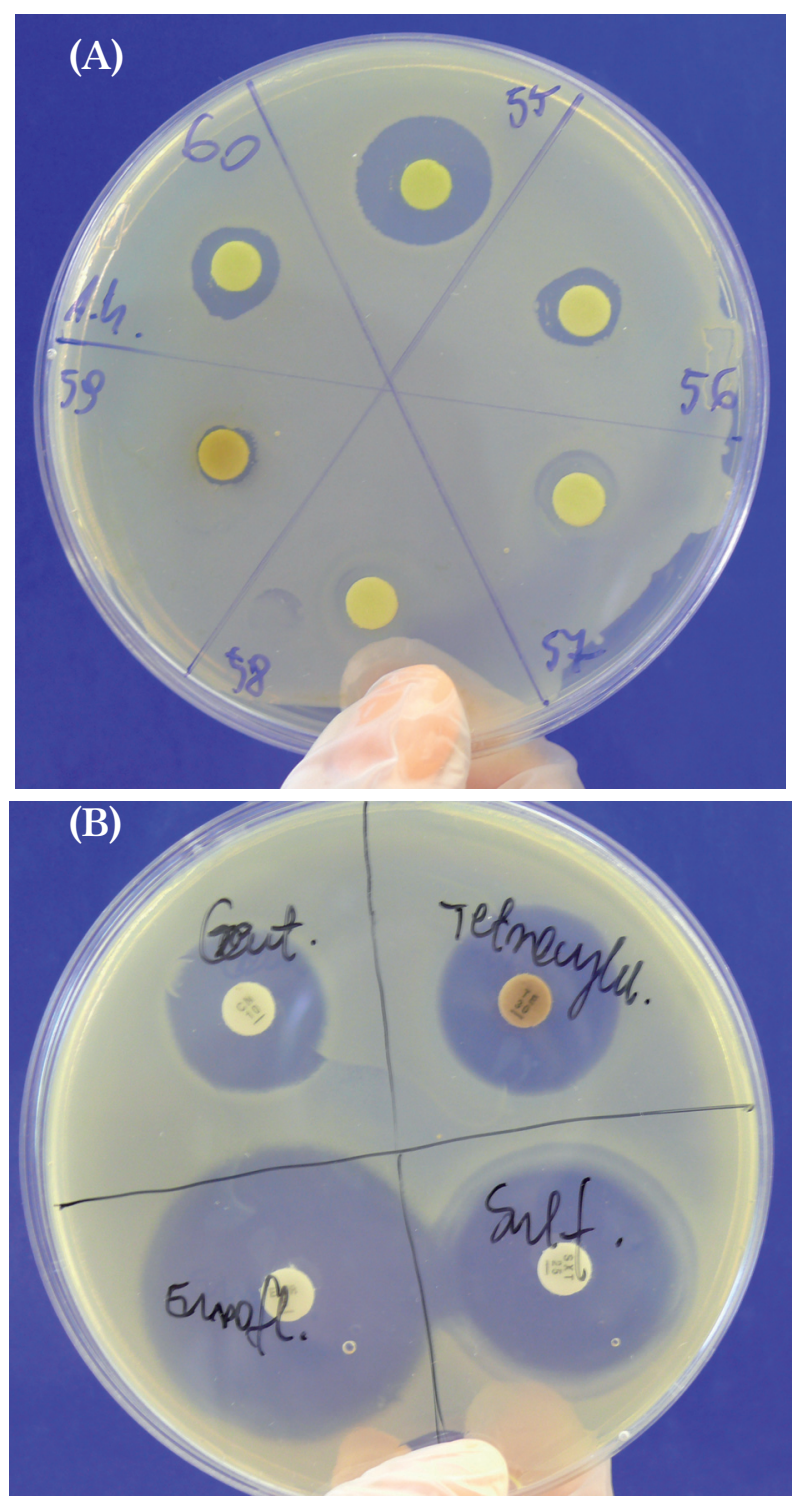

Figure 3. Antimicrobial activity of ethanolic extracts obtained from $F$. pumila (55) against A. hydrophila (A) and tested antibiotics measured as inhibition zone diameter.

albicans. Oxypeucedanin hydrate inhibited the growth of $S$. typhi, but was inactive against another five microorganisms (Juan et al. 1997).

Interestingly, ethanolic extracts obtained from Ficus species demonstrated different antibacterial activity against $A$. hydrophila inoculated with $200 \mu \mathrm{l}$ and $400 \mu \mathrm{l}$ of standardized inoculum $\left(10^{8} \mathrm{CFU} \mathrm{ml}^{-1}\right)$ of bacterium strain. Previous study using $200 \mu \mathrm{l}$ of $A$. hydrophila inoculum revealed that $F$. benghalensis, $F$. benjamina, $F$. binnendijkii, F. cyathistipula, F. deltoidea, F. erecta, $F$. erecta var. sieboldii, F. hispida, F. luschanthiana, F. lyrata, F. macrophylla, F. mucuso, F. natalensis subsp. leprieurii, $F$. natalensis subsp. natalensis, F. palmeri, $F$. platypoda, F. pumila, F. rubiginosa, F. sur, F. sycomorus, and F. villosa possessed good antibacterial activity (diameters of inhibition zones ranged from 10 to $14 \mathrm{~mm}$ ), while $A$. hydrophila was resistant against ethanolic exstracts from $F$. aspera, $F$. benjamina 'Reginald', $F$. binnendijkii 'Amstel Gold', F. binnendijkii 'Amstel King', $F$. carica, F. craterostoma, F. drupacea, F. drupacea 'Black Velvet', F. elastica, F. elastica 'Variegata', F. religiosa, F. sagittata, F. septica, and F. vasta (Tkachenko et al. 2016). On the other hand, in this study with $400 \mu \mathrm{l}$ of $A$. hydrophila inoculum, bacterium demonstrated the highest susceptibility to $F$. pumila leaves extract (diameters of inhibition zones ranged from 16 to $18 \mathrm{~mm}$ ), while intermediate susceptibility was demonstrated to ethanolic extracts obtained from $F$. benghalensis, $F$. benjamina, F. benjamina 'Reginald', F. binnendijkii, $F$. carica, F. cyathistipula, F. deltoidea, F. drupacea, F. drupacea 'Black Velvet', F. elastica, F. erecta, F. erecta var. sieboldii, F. hispida, F. lyrata, F. macrophylla, F. natalensis subsp. leprieurii, $F$. natalensis subsp. natalensis, F. palmeri, F. religiosa, F. rubiginosa, F. septica, and $F$. sycomorus leaves (Table 1 ).

In this study, among various species of Ficus with moderate activity against $A$. hydrophila, the highest antibacterial activity was noted in $F$. benghalensis, $F$. benjamina, F. deltoidea, F. hispida, and F. lyrata. The results demonstrate that $F$. benghalensis has intermediate in vitro activity against $A$. hydrophila. This data are consistent with the results of other authors. $F$. benghalensis bark exhibited significant antibacterial activity against $S$. aureus, $P$. aeruginosa, and $K$. pneumoniae (Gayathri et al. 2009). Aqueous and hexane aerial root extracts of $F$. benghalensis showed sustained activity against all bacterial strains and the highest activity was observed against $S$. aureus (Singh and Watal 2010). The antimicrobial activity of a methanolic extract was good and was more potent against B. subtilis (Jagtap et al. 2012). Verma et al. (2012, 2013) confirmed the immunostimulatory role of F. benghalensis (prop-roots) and L. leucocephala (pod 
seed) in Clarias gariepinus when supplemented in artificial feed. These authors evaluated the antibacterial activity of methanolic extracts of $F$. benghalensis (prop-root) by measuring the inhibition zone against the pathogenic bacteria E. coli and A. hydrophila. Moreover, juvenile $C$. gariepinus were fed a $5 \%$ powder of $F$. benghalensis with respective feeds for 20 days prior to the experiment. The immunomodulatory response conferred by the feed supplement was studied by challenging the fish intraperitoneally with $A$. hydrophila weekly. One set of fish, which were not challenged with $A$. hydrophila, was used as a negative control, to analyze any detrimental effect of the feed supplement, while the positive control comprised challenged fish fed with non-supplemented feed. Another two groups of fish were fed supplemented feeds and challenged with $A$. hydrophila. The fish fed supplemented feed showed increased lysozyme activity and a higher phagocytic index indicating an increased non-specific immune response (Verma et al. 2013). Moreover, serum lysozyme, tissue superoxide dismutase, percentage phagocytosis, phagocytotic index, nitric oxide (NO), total serum protein, and immunoglobulin increased significantly in the treated fish compared to the control fish (Verma et al. 2012).

Similar antibacterial activity was noted for the ethanolic extract from $F$. benjamina (Fig. 1). F. benjamina also of high medicinal potential. The plant is also used as antimicrobial, antinociceptive, antipyretic, hypotensive, and anti-dysentery remedy (Imran et al. 2014). Sirisha et al. (2010) suggest that the leaves, bark, and fruits of $F$. benjamina contain various bioactive constituents like cinnamic acid, lactose, naringenin, quercetin, caffeic acid, and stigmasterol. The fruit extract of $F$. benjamina exhibits both anti-tumor activity and significant antibacterial activities (Parveen et al. 2009). The medicinal importance of this plant encouraged us to carry out the antimicrobial study of the ethanolic extract from the leaves of $F$. benjamina plants against A. hydrophila. Imran et al. (2014) reveal that the extracts and fractions of stem, root, and leaves of $F$. benjamina exhibited considerable antimicrobial activity against four bacterial ( $P$. aerugonisa, E. coli ATCC 25922, B. subtilis JS 2004, B. cereus) and two fungal strains (Aspergillus niger ATCC 10595, C. albicans ATCC 32612). These researchers clearly demonstrate that all the butanol fractions exhibited strong inhibitory activity. The methanolic extract and n-butanolic fraction of the stem showed substantial activity. Moderate values were recorded for n-hexane, chloroform, and ethyl acetate (Imran et al. 2014). Parveen et al. (2009) report on the isolation and characterization of a new triterpene, (9,11),(18,19)-disecoolean-12-en-28-oic acid (1) along with $\beta$-amyrin (2). Compound 1 exhibited significant antimicrobial activity against Salmonella typhimurium (MTCC-98), C. albicans (IAO-109), S. aureus (IAO-SA-22), and $E$. coli (K-12) and low activity against $A$. niger (lab isolate ICAR) and A. brassicola (Parveen et al. 2009).

The ethanolic extracts from $F$. lyrata and $F$. hispida leaves inhibited the growth of $A$. hydrophila (Fig. 1B, 2B). Considerable $F$. lyrata antimicrobial activity is also reported in other similar studies. The ethyl acetate extract of $F$. lyrata latex comprises compounds with antibacterial and anticandidal properties that can be used as antimicrobial agents in new drugs to treat infectious diseases (Bidarigh et al. 2011). The methanolic extract had no effect against bacteria except for Proteus mirabilis, while the ethyl acetate extract inhibited the multiplication of five bacteria species (E. faecalis, Citrobacter freundii, P. aeruginosa, E. coli, and Proteus mirabilis) (Bidarigh et al. 2011). F. lyrata is reported to have numerous bioactive compounds such as arabinose, $\beta$-amyrins, $\beta$-carotenes, glycosides, $\beta$-setosterols, and xanthotoxol (Jeong and Lachance 2001, Vaya and Mahmood 2006). To identify the active substance responsible for the antibacterial activity, Rizvi et al. (2010) screened isolated pure compounds (FL-1-FL8) from $F$. lyrata for their inhibitory effect against the growth of various bacterial strains. They observed that only two compounds, i.e., ursolic acid (FL-1) and acacetin-7-O-neohesperidoside (FL-2), exhibited antibacterial activity. The Minimal Inhibitory Concentrations (MICs) were significantly lower against bacterial strains sensitive to the crude extract but also against $S$. typhi, S. paratyphi A, S. typhimurium, Vibrio cholerae, E. coli, K. pneumoniae and to E. coli and K. pneumoniae that produced extended-spectrum $\beta$-lactamases (ESBL). Thus, the range of activity against 
Gram negative bacteria was greatly enhanced on testing with pure compounds (Rizvi et al. 2010). Ursolic acid was more potent than acacetin-7-O-neohesperidoside. Ursolic acid is a triterpenoid sapogenin from the ursan group, whereas Acacetin-7-O-neohesperidoside is a flavonoid glycoside (Rizvi et al. 2010).

Experimental evidence presented by Rizvi et al. (2010) suggests that ursolic acid from $F$. lyrata has excellent antibacterial activity against several problematic bacteria like MRSA and the ESBL-producing bacteria Pseudomonas, Salmonella, Shigella, and Vibrio cholerae and other known pathogens that are drug resistant. Ursolic acid and Acacetin-7-O-neohesperidoside contribute significantly to the antimicrobial activity of the crude extract of $F$. lyrata (Rizvi et al. 2010). Ahmad and Beg (2001) have revealed that glycosides and saponins extracted from leaves using alcohol had biological effects, but they had no effects on C. albicans, S. aureus, or E. coli.

F. hispida was chosen for its abundance of alkaloids, carbohydrates, proteins and amino acids, sterols, phenols, flavonoids, gums and mucilage, glycosides, saponins, and terpenes (Ghosh et al. 2004). The broad antibacterial activities of this extract, apparently, is explained by the plant's secondary metabolites. Sirisha et al. (2010) and Salem et al. (2013) report that the therapeutic properties of Ficus species could be attributed to the presence of a wide range of phytochemical compounds. In general, Ficus species are rich sources of polyphenolic compounds. In particular, flavonoids and isoflavonoids are responsible for the extract's strong antioxidant activity that could be useful in preventing diseases involving oxidative stress (Sirisha et al. 2010). A wide variety of bioactive compounds from different phytochemical groups like alkaloids, carbohydrates, proteins and amino acids, sterols, phenols, flavonoids, gums and mucilage, glycosides, saponins, and terpenes are thought to be key to the antimicrobial activity of F. hispida (Ali and Chaudhary 2011). Two substantial phenanthroindolizidine alkaloids, 6-O-methyltylophorinidine and 2-demethoxytylophorine, and a novel biphenylhexahydroindolizine hispidine from stem and leaves of $F$. hispida were isolated by Venkatachalam and Mulchandani (1982). Recently, hispidin has been reported to have anticancer activity (Ali and Chaudhary 2011). All the phenolic acids detected are known to have antimicrobial and antioxidant properties (Jaafar et al. 2012). The antimicrobial properties of $F$. hispida extract could stem from its constituents.

The antibacterial activity of this extract is possibly linked to the presence of flavonoid compounds. The antibacterial activity of flavonoid compounds isolated from plant species are well documented (Hendrich 2006, Ferrazzano et al. 2011, Farzaei et al. 2013). The high amount of epicatechin found in F. deltoidea could be responsible for the strong radical scavenging activities found in the extract. A positive correlation was observed between the flavonoid constituents present and the radical scavenging activities of aqueous extracts of $F$. deltoidea (Dzolin et al. 2015). Chemical analysis found four phenolic compounds (chlorogenic, p-coumaric, ferulic and syringic acids) in the roots, three (chlorogenic p-coumaric and ferulic acids) in the stems, and only one (caffeic acid) in the leaves of $F$. benjamina (Imran et al. 2014). A glucoside, bengalenoside, was isolated from $F$. benghalensis and evaluated for hypoglycemic activity (Garg and Paliwal 2011). The phytochemical screening of $F$. benghalensis revealed the presence of saponins, tannins, and flavonoids in aqueous and methanolic extracts (Aswar et al. 2008). Levels of total phenolic, total flavonol, and total flavonoid compounds in aerial roots in $70 \mathrm{mg}$ per g of extract, $3 \mathrm{mg}$ per g quercetin equivalent, and $5 \mathrm{mg}$ quercetin equivalent per g extract have also been reported (Sharma et al. 2009). Some natural compounds, i.e., glucoside, 20-tetratriaconthene-2-one, 6-heptatriacontene-10-one, pentariacontan-5-one, ß-sitosterol- $\alpha$-D-glucose, and meso-inositol, have been isolated from the bark (Subramanian and Misra 1978).

Kumar and Pandey (2013) suggest that antibacterial flavonoids might have multiple cellular targets rather than one specific site of action. Moreover, they also suggest that one of their molecular actions is to form complexes with proteins through nonspecific forces such as hydrogen bonding and hydrophobic effects, as well as by covalent bond formation. Thus, their mode of antimicrobial action could be related to their ability to inactivate microbial adhesins, enzymes, cell envelope transport proteins, and so forth. 
Lipophilic flavonoids could also disrupt microbial membranes (Kumar and Pandey 2013).

It is desirable that antibiotic use in fish cultures be reduced and replaced by natural medicines to prevent the emergence of bacterial resistance in aquatic animals and their environment. Antibiotics are used widely in fish farms as bacterial infection prophylaxis and as growth promoters. Despite widespread use, the use of this drug class in fish is unregulated (Rigos and Troisi 2005). Therefore, plant extracts can be more effective for preventive and therapeutical aims in organic aquaculture. In the present study, the ethanolic extracts obtained from various species of Ficus leaves showed varying inhibitory activities against $A$. hydrophila. Consequently, the screening results of this study confirm the possible use of medicinal plants, Ficus in particular, as a source of antimicrobial agents.

\section{Conclusions}

The results obtained highlight the interesting antimicrobial potency of various Ficus species against A. hydrophila, and provide a scientific basis for the traditional use of these species. The results demonstrate that various species of Ficus had intermediate antibacterial in vitro activity against $A$. hydrophila. The highest antibacterial activity against $A$. hydrophila was noted in F. pumila, F. benghalensis, F. benjamina, F. deltoidea, F. hispida, and F. lyrata. Ficus spp. leaves possess great medicinal potential for bacterial and fungal infection therapy and could be used as natural antiseptics and antimicrobial agents in veterinary medicine. Further studies should be conducted to verify this activity against other pathogenic bacteria occurring in aquaculture and to confirm immune response involvement and their potential as virulence factor inhibitors. These products can be used in aquaculture as therapeutic and prophylactic agents with antimicrobial properties against fish pathogens. The results of the present study permit concluding that the plant extracts studied could be potential sources of new antimicrobial drugs. Finally, further investigation is necessary to identify the bioactive compounds that can be subjected to detailed pharmacological studies and the development of clinical applications.

Author contributions. H.T. and L.B. performed the experiment, analyzed the data, and wrote the manuscript, E.T.-M. performed disk diffusion method, Z.O. analyzed the data.

\section{References}

Ahmad L., Beg A.Z. 2001 - Antimicrobial and phytochemical studies on 45 Indian medicinal plants against multidrug resistant human pathogens - J. Ethnopharmacol. 74: 113-123.

Ahmad S., Rao H., Akhtar M., Ahmad I., Hayat M.M., Iqbal Z., Nisar-ur-Rahman 2011 - Phytochemical composition and pharmacological prospectus of Ficus bengalensis Linn. (Moraceae) - A review - J. Med. Plants Res. 5: 6393-6400.

Ali M., Chaudhary N. 2011 - Ficus hispida Linn.: A review of its pharmacognostic and ethnomedicinal properties Pharmacogn. Rev. 5: 96-102.

Ardo L., Yin G., Xu P., Varadi L., Szigeti G., Jeney Z., Jeney G. 2008 - Chinese herbs (Astragalus membranaceus and Lonicera japonica) and boron enhance the non-specific immune response of Nile tilapia (Oreochromis niloticus) and resistance against Aeromonas hydrophila Aquaculture 275: 26-33.

Arunachalam K., Parimelazhagan T. 2013 Anti-inflammatory, wound healing and in-vivo antioxidant properties of the leaves of Ficus amplissima Smith J. Ethnopharmacol. 145: 139-145.

Aswar M., Aswar U., Watkar B., Vyas M., Wagh A., Gujar K.N. 2008 - Anthelmintic activity of Ficus benghalensis Int. J. Green Pharma 2: 170-172.

Austin B., Austin D.A. 2007 - Diseases of Farmed and Wild Fish. $4^{\text {th }}$ ed. - Springer-Praxis Publishing, Chichester, United Kingdom.

Bauer A.W., Kirby W.M., Sherris J.C., Turck M. 1966 - Antibiotic susceptibility testing by a standardized single disk method - Am. J. Clin. Pathol. 45: 493-496.

Bidarigh S., Khoshkholgh Pahlaviani M.R.M., Massiha A., Issazadeh Kh. 2011 - In vitro anti-Candida activity of Ficus lyrata L. ethyl acetate latex extract and nystatin on clinical isolates and standard strains of Candida albicans - International Conference on Biotechnology and Environment Management, IPCBEE, 18: 115-119.

Brummitt R.K., Powell C.E. 1992 - Authors of Plant Names Kew, Royal Botanic Gardens. 
Cipriano R.C. 2001 - Aeromonas hydrophila and motile aeromonad septicemias of fish - U.S. Department of the Interior, Fish and Wildlife Service, Washington, DC.

Cipriano R.C., Austin B. 2011 - Furunculosis and Other Aeromonad Diseases - In: Fish Diseases and Disorders Vol. 3: Viral, Bacterial and Fungal Infections, $2^{\text {nd }}$ Edition (Eds) P.T.K. Woo, D.W. Bruno, CAB International, Oxfordshire, United Kingdom: 424-483.

Dangarembizi R., Erlwanger K.H., Moyo D., Chivandi E. 2012 - Phytochemistry, pharmacology and ethnomedicinal uses of Ficus thonningii (Blume Moraceae): a review Afr. J. Tradit. Complement. Altern. Med. 10: 203-212.

Davis E.B., Schmidt D. 1996 - Guide to information sources in the botanical sciences. 2 ed. - Englewood, Colo, Libraries Unlimited. p. 188.

Dzolin S., Ahmad R., Zain M.M., Ismail M.I. 2015 - Flavonoid distribution in four varieties of Ficus deltoidea (Jack) - J. Med. Plant Herb. Ther. Res. 3: 1-9.

Farsi E., Ahmad M., Hor S.Y., Ahamed M.B., Yam M.F., Asmawi M.Z. 2014 - Standardized extract of Ficus deltoidea stimulates insulin secretion and blocks hepatic glucose production by regulating the expression of glucose-metabolic genes in streptozitocin-induced diabetic rats - BMC Complement. Altern. Med. 14: 220.

Farzaei M.H., Abbasabadi Z., Ardekani M.R., Rahimi R., Farzaei F. 2013 - Parsley: a review of ethnopharmacology, phytochemistry and biological activities - J. Tradit. Chin. Med. 33: 815-826.

Ferrazzano G.F., Amato I., Ingenito A., Zarrelli A., Pinto G., Pollio A. 2011 - Plant polyphenols and their anti-cariogenic properties: a review - Molecules 16: 1486-1507.

Friedman M., Henika P.R., Mandrell R.E. 2002 - Bactericidal activities of plant essential oils and some of their isolated constituents against Campylobacter jejuni, Escherichia coli, Listeria monocytogenes and Salmonella enterica - J. Food Prot. 65: 1545-1560.

Garg V.K., Paliwal S.K. 2011 - Wound-healing activity of ethanolic and aqueous extracts of Ficus benghalensis - J. Adv. Pharm. Technol. Res. 2: 110-114.

Gayathri M., Kannabiran K. 2009 - Antimicrobial activity of Hemidesmus indicus, Ficus bengalensis and Pterocarpus marsupium Roxb - Indian J. Pharm. Sci. 71: 578-581.

Ghosh R., Sharatchandra K.H., Rita S., Thokchom I.S. 2004 Hypoglycemic activity of Ficus hispida (bark) in normal and diabetic albino rats - Indian J. Pharmacol. 36: 222-225.

Giri S.S., Sen S.S., Chi C., Kim H.J., Yun S., Park S.C., Sukumaran V. 2015 - Effect of guava leaves on the growth performance and cytokine gene expression of Labeo rohita and its susceptibility to Aeromonas hydrophila infection - Fish Shellfish Immunol. 46: 217-224.

Gul-e-Rana, Karim S., Khurhsid R., Saeed-ul-Hassan S., Tariq I., Sultana M., Rashid A.J., Shah S.H., Murtaza G.
2013 - Hypoglycemic activity of Ficus racemosa bark in combination with oral hypoglycemic drug in diabetic human - Acta Pol. Pharm. 70: 1045-1049.

Harikrishnan R., Balasundaram C. 2005 - Antimicrobial activity of medicinal herbs in vitro against fish pathogen, Aeromonas hydrophila - Fish Pathol. 40: 187-189.

Hendrich A.B. 2006 - Flavonoid-membrane interactions: possible consequences for biological effects of some polyphenolic compounds - Acta Pharmacol. Sin. 27: 27-40.

Ilyanie Y., Wong T.W., Choo C.Y. 2011 - Evaluation of hypoglycemic activity and toxicity profiles of the leaves of Ficus deltoidea in rodents - J. Complement. Integr. Med. 8.

Imran M., Rasool N., Rizwan K., Zubair M., Riaz M., Zia-Ul-Haq M., Rana U.A., Nafady A., Jaafar H.Z. 2014 Chemical composition and Biological studies of Ficus benjamina - Chem. Cent. J. 8: 12.

Jagtap S.G., Shelar R.S., Munot N.M., Ghante M.R., Sawant S.D. 2012 - Antimicrobial activity of Ficus glomerata Linn. bark - Int. Res. J. Pharm. 3: 281-284.

Jeong W.S., Lachance P.A. 2001 - Phytosterols and fatty acids in fig (Ficus lyrata var. mission) fruit and tree components - Food Chem. Toxicol. 66: 278-281.

Jones S.D., Wipff J.K., Montgomery P.M. 1997 - Vascular Plants of Texas: A Comprehensive Checklist Including Synonymy, Bibliography, and Index - University of Texas Press.

Juan E., Rideout J., Ragasa C. 1997 - Bioactive furanocoumarin derivatives from Ficus pumila (Moraceae) - Philipp. J. Sci. 126:143-153.

Jaafar H.Z., Ibrahim M.H., Karimi E. 2012 - Phenolics and flavonoids compounds, phenylanine ammonia lyase and antioxidant activity responses to elevated $\mathrm{CO}_{2}$ in Labisia pumila (Myrisinaceae) - Molecules 17: 6331-6347.

Kumar S., Pandey A.K. 2013 - Chemistry and biological activities of flavonoids: an overview - Sci. World J. 2013: 162750.

OIE 2000 - Diagnostic Manual for aquatic animal diseases Fish Diseases Commission, Paris, France.

Okoth D.A., Chenia H.Y., Koorbanally N.A. 2013 - Antibacterial and antioxidant activities of flavonoids from Lannea alata (Engl.) Engl. (Anacardiaceae) - Phytochem. Lett. 6: 476-481.

Parveen M., Ghalib R.M., Mehdi S.H., Rehman S.Z., Ali M. 2009 - A new triterpenoid from the leaves of Ficus benjamina (var. comosa) - Nat. Prod. Res. 23: 729-736.

Rigos G., Troisi G.M. 2005 - Antibacterial agents in Mediterranean finfish farming: A sinopsis of drug pharmacokinetics in important euryhaline fish species and possible environmental implications - Rev. Fish Biol. Fish. 15: 53-73. 
Rizvi W., Rizvi M., Kumar R., Kumar A., Shukla I., Parveen M. 2010 - Antibacterial activity of Ficus lyrata - An in vitro study - Int. J. Pharmacol. 8: 7.

Sahu S., Das B.K., Pradhan J., Mohapatra B.C., Mishra B.K., Sarangi N. 2007 - Effect of Magnifera indica kernel as a feed additive on immunity and resistance to Aeromonas hydrophila in Labeo rohita fingerlings - Fish Shellfish Immunol. 23: 109-118.

Salem M.Z.M., Salem A.Z.M., Camacho L.M., Ali H.M. 2013 Antimicrobial activities and phytochemical composition of extracts of Ficus species: An over view - Afr. J. Microbiol. Res. 7: 4207-4219.

Sharma Madhuri, Mandloi A.K., Pandey Govind, Sahni Y.P. 2012 - Antimicrobial activity of some medicinal plants against fish pathogens - Int. Res. J. Pharm. 3: 28-30.

Singh R.K., Watal G. 2010 - Antimicrobial potential of Ficus bengalensis aerial roots - Int. J. Pharm. Biol. Sci. 1: 1-9.

Sirisha N., Sreenivasulu M., Sangeeta K., Chetty C.M. 2010 Antioxidant properties of Ficus species, a review - Int. J. Pharm. Tech. Res. 4: 2174-2182.

Subramanian P.M., Misra G.S. 1978 - Chemical constituents of Ficus bengalensis (part II) - Pol. J. Pharmacol. Pharm. 30: 559-562.

Sukumaran V., Park S.C., Giri S.S. 2016 - Role of dietary ginger Zingiber officinale in improving growth performances and immune functions of Labeo rohita fingerlings - Fish Shellfish Immunol. 57: 362-370.

Tkachenko H., Buyun L., Terech-Majewska E., Osadowski Z., Sosnovskyi Y., Honcharenko V., Prokopiv A. 2016 - The antimicrobial activity of some ethanolic extracts obtained from Ficus spp. leaves against Aeromonas hydrophila Trudy VNIRO 162: 172-183.

Tukmechi A., Ownagh A., Mohebbat A. 2010 - In vitro antibacterial activities of ethanol extract of Iranian propolis (EEIP) against fish pathogenic bacteria (Aeromonas hydrophila, Yersinia ruckeri and Streptococcus iniae Braz. J. Microbiol. 41: 1086-1092.

Vaya J., Mahmood S. 2006 - Flavonoid content in leaf extracts of the fig (Ficus carica L.), carob (Ceratonia siliqua L.) and pistachio (Pistacia lentiscus L.) Biofactors 28: 169-175.

Venkatachalam S.R., Mulchandani N.B. 1982 - Isolation of phenanthroindolizidinealkaloids and a novel biphenylhexahydroindolizine alkaloid from Ficus hispida - Naturwissenschaften 69: 287-288.

Verma V.K., Rani K.V., Sehgal N., Prakash O. 2012 Immunostimulatory response induced by supplementation of Ficus benghalensis root powder, in the artificial feed the Indian freshwater murrel, Channa punctatus - Fish Shellfish Immunol. 33: 590-596.

Verma V.K., Rani K.V., Sehgal N., Prakash O. 2013 Immunostimulatory effect of artificial feed supplemented with indigenous plants on Clarias gariepinus against Aeromonas hydrophila - Fish Shellfish Immunol. 35: 1924-1931.

Zepeda-Velázquez A.P., Vega-Sánchez V., Salgado-Miranda C., Soriano-Vargas E. 2015 - Histopathological findings in farmed rainbow trout (Oncorhynchus mykiss) naturally infected with 3 different Aeromonas species - Can. J. Vet. Res. 79: 250-254. 